\title{
CHARACTERIZATION IN TERMS OF COMPOSITION AND PHYTOTOXICITY OF AQUEOUS SPORES EXTRACT
}

\author{
Oana-Alexandra Drăghiceanu ${ }^{1}$, Anca Nicoleta Șuțan ${ }^{1}$, Codruța Mihaela Dobrescu ${ }^{1}$, \\ Nicoleta Doruța Bătut-Andrei ${ }^{1}$, Liliana Cristina Soare ${ }^{1 *}$, Carmen Mihaela Topală ${ }^{1}$
}

${ }^{1}$ University of Pitești, Târgu din Vale Street, 110040, Pitești, România

\section{Natural Sciences}

\begin{abstract}
In this study, we used aqueous extracts of fern spores and solution of $\mathrm{AgNO}_{3}$ and $\mathrm{HAuCl}_{4}$ for the synthesis of bimetallic nanoparticles Au:Ag in different proportions: 1:1 and 1:10. The spores used come from 2 species of ferns: Asplenium scolopendrium and Dryopteris filix-mas. For the characterization of the extracts with or without bimetallic nanoparticles we applied Fourier transform infrared spectroscopy (FT-IR). Phytotoxicity was tested using Pisum sativum seeds. Each extract was tested in 2 dilutions: 1:10 (D10) and 1:100 (D100). The parameters, which we determinate were the root and stem growth and fresh biomass. Root growth was stimulated in variants with Asplenium scolopendrium extract: without nanoparticles both dilution and with Au:Ag nanoparticles 1:10 D10. The highest values obtained for the stem were at D10 at the variants with Asplenium scolopendrium extract with or without bimetallic nanoparticles. The influence of extracts on fresh biomass was smaller than on the growth of root and stem.
\end{abstract}

Keywords: bimetallic nanoparticles, extracts, fern spores, FT-IR, Pisum sativum.

\section{INTRODUCTION}

Because of their unique physical and chemical properties, nanoparticles (NPs) are used in numerous biological, chemical, optical and electronic applications (Rahman et al., 2020). Green synthesis of nanoparticles it is simple, clean, safe and environmentally friendly (Rani et al., 2022). Having antibacterial and biocidal properties, Ag NPs are frequently used in medical application, cosmetics and food services (Jogaiah et al., 2021). AuNPs are easy to synthesize and are stable; they may have different size and relatively low toxicity. AuNPs can be used as an agent for gene/drug delivery because they have small size they can enter in the cell by endocytosis or diffusion (Kumar et al., 2018). Metal combinations are another important subject that has been in the attention of researchers due to their new characteristics different from the properties of the components (Dobrucka et al., 2021). Green synthesized bimetallic Au-Ag nanoparticles have interesting properties and higher catalytic efficiencies than Au and Ag monometallic nanoparticles (Sahu et al., 2020). Ten years before the beginning of the nano-ecotoxicology field, researchers said that NPs can have a negative effect on biota by generating ROS (Khan et al., 2021). Plants are one of the most important forms of life because they are the primary producers in the ecosystem. The effect of nanoparticles on plants varies upon their concentrations, properties (physical and chemical) and 


\section{Current Trends in Natural Sciences}

Vol. 10, Issue 20, pp. 53-60, 2021

https://doi.org/10.47068/ctns.2021.v10i20.008

Current Trends in Natural Sciences (on-line)

ISSN: 2284-953X

Current Trends in Natural Sciences (CD-Rom)

ISSN: 2284-9521

ISSN-L: 2284-9521

ISSN-L: 2284-9521

plant species; various nanoparticles can increase biomass productivity and germination rate (Aqeel et al., 2021). Plants can promote the development of nanotechnology through preparation of nanoparticles (green synthesis) and in turn nanoparticles can promote the health of plants by acting like growth regulators, pesticides, fertilizers, antimicrobial agents, targeted transporters, biosensors (Hu and Xianyu, 2021).

This study determined the capacity of aqueous extracts of fern spores to produce bimetallic AuAgNPs and to establish the potential toxicity of the extracts with or without nanoparticles.

\section{MATERIALS AND METHODS}

In this study, we used aqueous extracts of fern spores (Asplenium scolopendrium - As and Dryopteris filix-mas - Dfm) and solutions of $\mathrm{AgNO}_{3}$ and $\mathrm{HAuCl}_{4}$ for the synthesis of bimetallic nanoparticles $\mathrm{Au}: \mathrm{Ag}$ in different proportions (1:1 and 1:10). For the characterization of the extracts with or without bimetallic nanoparticles, we applied Fourier transform infrared spectroscopy (FTIR). The spectral measurements were made using a FTIR Jasco 6300 spectrometer with an ATR accessory equipped with a diamond crystal (Pike Technologies). The spectra were recorded in the region of $400-4000 \mathrm{~cm}^{-1}$, detector TGS, apodization Cosine. The spectral data were processed with JASCO Spectra Manager II software.

Phytotoxicity was tested using pea seeds. The seeds of Pisum sativum variety Alvesta were bought from Agricultural Research and Development Station Pitești, Albota. The hydration and the immersion in the test solution lasted one hour each. Each extract (Table 1) was tested in 2 dilutions: 1:10 (D10) and 1:100 (D100), and for Control we used distilled water. After immersion in the test solution, the seeds were placed in Petri dishes on filter paper and watered periodically with distilled water. The Petri dishes were placed in the dark until the measurements were made. For each variant, 10 seeds from each plant species were used, and the experiment had three repetitions. After five days from the beginning of the experiment the following parameters were determinate: the growth of root and stem and fresh biomass. With the help of SPSS program - version16 for Windows, we calculated the average and compared them with Duncan test.

Table 1. Tested variants

\begin{tabular}{|l||l|}
\hline Variants & Contain \\
\hline Control & Distilled water \\
\hline AA M & Aqueous extract obtained from As spores \\
\hline AA 1:1 & Aqueous extract obtained from $\mathrm{As}$ spores with $\mathrm{Au}-\mathrm{Ag}$ NPs 1:1 \\
\hline AA 1:10 & Aqueous extract obtained from As spores with $\mathrm{Au}-\mathrm{Ag} \mathrm{NPs} 1: 10$ \\
\hline DA M & Aqueous extract obtained from Dfm spores \\
\hline DA 1:1 & Aqueous extract obtained from Dfm spores with $\mathrm{Au}-\mathrm{Ag}$ NPs 1:1 \\
\hline DA 1:10 & Aqueous extract obtained from Dfm spores with $\mathrm{Au}-\mathrm{Ag}$ NPs 1:10 \\
\hline
\end{tabular}

\section{RESULTS AND DISCUSSIONS}

In extracts with nanoparticles, the carbonyl group at $1635 \mathrm{~cm}^{-1}$ shows an increased intensity as a result of the capture/reduction of the metals. It was also confirmed that the carbonyl group from the protein and amino acid had stronger ability to bind with metal nanoparticles or act as stabilizing agents (Table 2, Fig. 1-6).

A difference was witnessed for two peaks at $1419 \mathrm{~cm}^{-1}$ and $3225 \mathrm{~cm}^{-1}$ in the case of AA 1:1 and AA1:10. 


\section{Current Trends in Natural Sciences}

Vol. 10, Issue 20, pp. 53-60, 2021

https://doi.org/10.47068/ctns.2021.v10i20.008

Current Trends in Natural Sciences (on-line)

ISSN: 2284-953X

Current Trends in Natural Sciences (CD-Rom)

ISSN: 2284-9521

ISSN-L: 2284-9521

ISSN-L: 2284-9521

The signals at frequencies above $3345-3255 \mathrm{~cm}^{-1}$ can be assigned to those molecules that are involved in hydrogen-bonding interactions. The data in Figures 4-6 and Table 2 show distinct differences for the different nanoparticles. As the solvent water, exhibits systematically varying dielectric constants because of their joint hydroxyl group and the remaining group with decreasing polarity (Kiefer and col., 2015). Hence, they can interact with the nanoparticle surface via different mechanisms such as hydrogen-bonding, polar interactions, and van der Waals forces. The $\mathrm{OH}$ band is highly sensitive to changes in the hydrogen-bonding network, so a difference was witnessed the peak at $3225 \mathrm{~cm}^{-1}$ in the case of AA 1:1 $\left(3241 \mathrm{~cm}^{-1)}\right.$ and AA1:10 $\left(3255 \mathrm{~cm}^{-1}\right)$.

Root growth in $P$. sativum was stimulated in variants with Asplenium scolopendrium extract: without nanoparticles both dilution and with Au:Ag NPs 1:10 D10 (Fig.7a). The highest values obtained for the stem were at D10 at the variants with Asplenium scolopendrium extract with or without bimetallic nanoparticles (Fig.7b). The results recorded, both for root and stem, for the rest of variants were similar to the control or smaller, but the differences were not significant. The influence of extracts on fresh biomass was smaller than on root and stem growth (Fig.7c).

In the experiment performed by Rani et al. (2021) the plants from Control were similar to the plants from the variants with AgNP, and the concentration of nanoparticles within plants was low. At low concentrations, AgNPs can have a positive effect on Pisum sativum on protein and carbohydrate content (Mehmood and Murtaza, 2017), fresh and dry biomass and photosynthesis (Prażak et al., 2020) and root length (Barabanov et al., 2018).

Table 2. FTIR

\begin{tabular}{|c|c|c|c|c|c|c|}
\hline . & \multicolumn{5}{|c|}{ FTIR band absorption peaks $\left(\mathrm{cm}^{-1}\right)$} & Assignments \\
\hline DA M & DA 1:1 & DA 1:10 & AA M & AA 1:1 & AA 1:10 & \\
\hline 722 & 723 & 722 & 722 & 723 & 722 & $\begin{array}{l}\text { Out-of-plane bending vibrations (Schulz and } \\
\text { Baranska, 2007) }\end{array}$ \\
\hline 1338 & 1339 & 1339 & 1338 & 1339 & 1339 & $\begin{array}{l}\mathrm{CH}_{2} \text { wagging (Yang et al., 2005; Lucassen et } \\
\text { al., 1998; Mordechai et al., 2000) }\end{array}$ \\
\hline 1397 & 1397 & 1397 & 1419 & 1397 & 1397 & $8 \mathrm{CH} 3$ \\
\hline 1435 & 1435 & 1435 & 1435 & 1435 & 1435 & $\delta\left(\mathrm{CH}_{2}\right)$ (polysaccharides, cellulose) \\
\hline 1456 & 1456 & 1456 & 1456 & 1456 & 1456 & $\begin{array}{l}\text { Asymmetric } \mathrm{CH}_{3} \text { bending modes of the } \\
\text { methyl groups of proteins (Shetty et al., 2006) }\end{array}$ \\
\hline 1473 & 1473 & 1473 & 1473 & 1473 & 1473 & $\begin{array}{l}\mathrm{CH}_{2} \text { bending of the methylene chains in } \\
\text { lipids }\end{array}$ \\
\hline 1488 & 1488 & 1488 & 1488 & 1488 & 1488 & $\mathrm{C}=\mathrm{C}$, deformation C-H (Shetty et al., 2006) \\
\hline 1507 & 1507 & 1507 & 1507 & 1507 & 1507 & $\begin{array}{l}\text { In-plane CH bending vibration from the } \\
\text { phenyl rings (Schulz and Baranska, 2007) }\end{array}$ \\
\hline 1540 & 1540 & 1540 & 1540 & 1540 & 1540 & $\begin{array}{l}\text { Protein amide II absorption- predominately } \\
\beta \text {-sheet of amide II }\end{array}$ \\
\hline 1558 & 1558 & 1558 & 1558 & 1558 & 1558 & $\begin{array}{l}\text { CO stretching (Wang et al., 1997) } \\
\text { Predominately a-sheet of amide II (Amide II } \\
\text { band mainly stems from the C-N } \\
\text { stretching and C-N-H bending vibrations } \\
\text { weakly coupled to the C=O stretching } \\
\text { mode) (Eckel et al., 2001) }\end{array}$ \\
\hline 1636 & 1635 & 1636 & 1636 & 1636 & 1635 & $\begin{array}{l}\text { Amide I band (arises from } \mathrm{C}=\mathrm{O} \text { stretching } \\
\text { vibrations) (Huleihel et al., 2002) }\end{array}$ \\
\hline 1730 & 1732 & 1732 & 1732 & 1732 & 1732 & $\mathrm{C}=\mathrm{O}$ band \\
\hline 3245 & 3269 & 3269 & 3255 & 3241 & 3255 & Stretching O-H \\
\hline
\end{tabular}




\section{Current Trends in Natural Sciences}

Vol. 10, Issue 20, pp. 53-60, 2021

https://doi.org/10.47068/ctns.2021.v10i20.008

Current Trends in Natural Sciences (on-line)

Labeeb et al. (2020) observed that all seedling growth parameters in Pisum sativum, except the root length, were reduced after AgNPs exposure. AgNPs with size over $22 \mathrm{~nm}$, in 1000-3000 $\mu \mathrm{M}$ concentration, produced a decline in plant growth and synthesis of plant pigments in Pisum sativum (Tripathi et al., 2017).

The cytotoxicity of AuNPs varies upon their concentration, particle size and shape. At lower concentration they stimulate vegetative growth and improved free radical scavenging potential and antioxidant enzymatic activities (Siddiqi and Husen, 2016). According to Zhu et al. (2012) AuNPs uptake and distribution depend on both nanoparticle surface charge and plant species. Positively charged AuNPs are taken up by plant roots, while negatively charged AuNPs are translocated into plant stems.

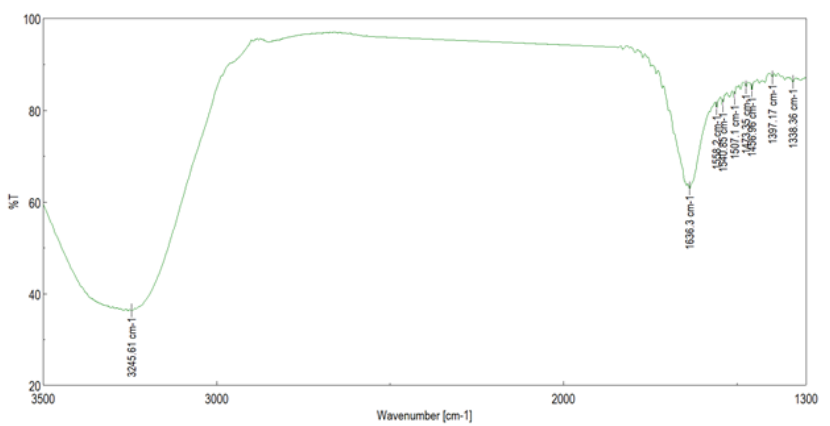

Fig.1 ATR-FTIR spectrum DA M

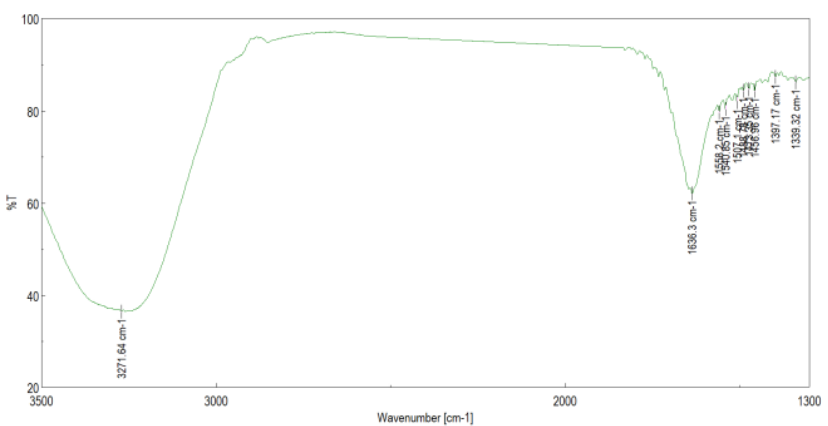

Fig.3 ATR-FTIR spectrum DA 1:10

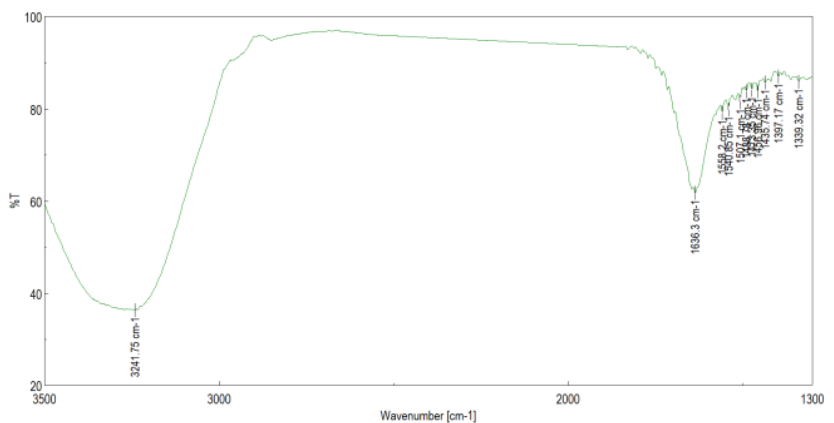

Fig.5 ATR-FTIR spectrum AA 1:1

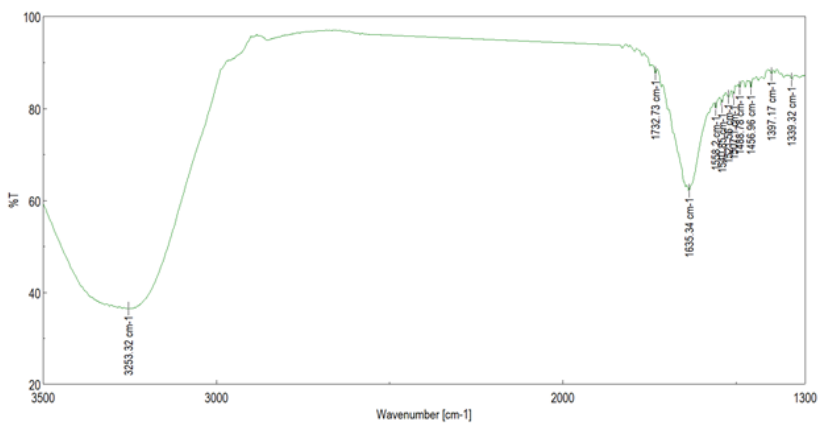

Fig.2 ATR-FTIR spectrum DA 1:1

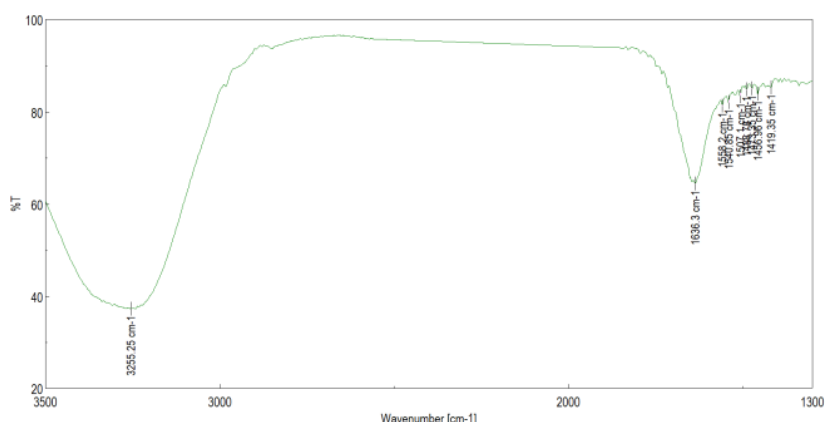

Fig.4 ATR-FTIR spectrum AA M

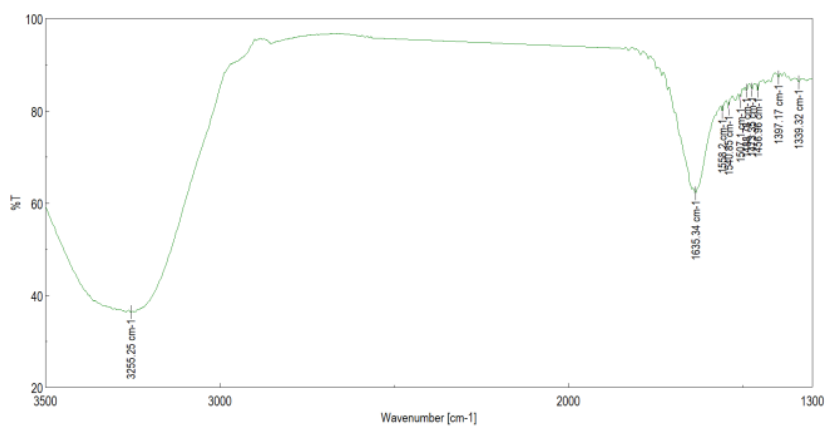

Fig.6 ATR-FTIR spectrum AA 1:10 

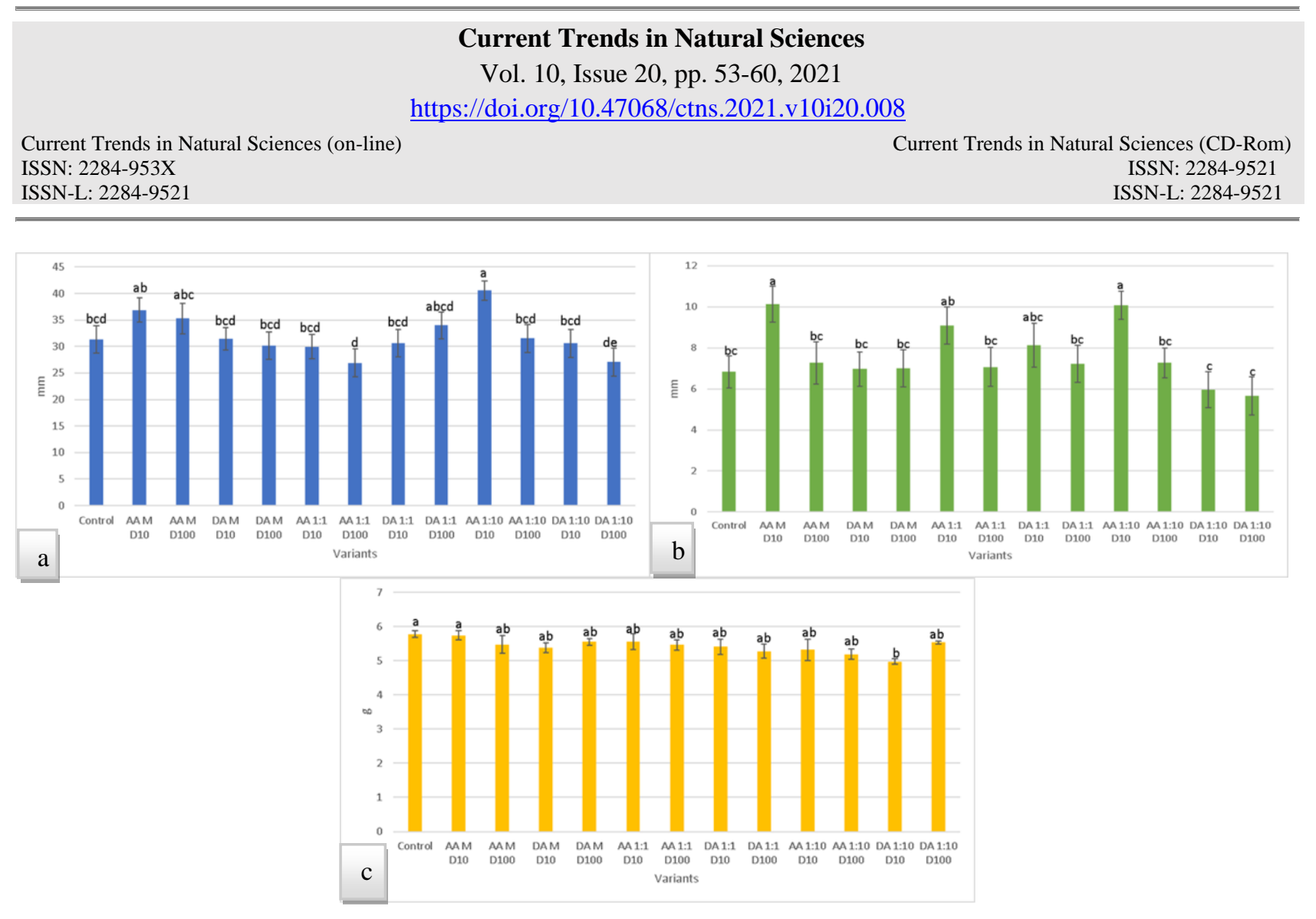

Fig.7 Extracts influence on Pisum sativum: a) root growth; b) stem growth; c) fresh biomas

Ndeh et al. (2017) observed a slight decrease in rice root and shoot lengths compared to the control, after AuNP exposure. The root lengths of Arabidopsis thaliana seedlings were reduced, after AuNPs exposure, by 75\% (Taylor et al., 2014), while at Brassica juncea the influence on growth parameters was positive (Arora et al., 2012).

AuNPs and AgNPs didn't stimulate the germination of seeds in Ficus plants, but they had a positive impact on Mimusops laurifolia seedlings by enhancing leaf growth (Alshehddi and Bokhari, 2020).

Jurkow et al. (2020) studied the antioxidant potential of oakleaf lettuce seedlings sprayed with AuNPs and AgNPs in different concentrations. They observed that the total peroxidase activity increased after applying Au-NPs, but decreased after Ag-NPs treatment, while the carotenoid content increased in both treatments.

At high concentrations, $\mathrm{Ag}, \mathrm{Au}$ and $\mathrm{Cu}$ nanoparticles showed a high level of toxicity and increased production of secondary metabolites, phenolic content, flavonoids, antioxidant activity, total protein content (Hussain et al., 2017).

The effect of bimetallic nanoparticles varies upon species: Ag/AuNPs were most toxic to Lepidium sativum and least toxic to Linum flavum, while for Zea mays, Solanum lycopersicum var. cerasiforme and Salvia hispanica seeds the phytotoxicity was similar (Szymaski and Dobrucka, 2020). After the nanoparticles penetrate the seeds, the effects they cause on the germination and growth of the seeds are long-lasting; the changes can be significant and can affect the biochemical profile (Hussain et al., 2018).

Ghosh et al. (2021) reported no phytotoxic effect of the biosynthesized AuNPs and Au-Ag NPs $(\leq 100 \mu \mathrm{g} / \mathrm{ml})$ on lentil seeds, while AgNPs exhibited a little phytotoxicity at higher $(100 \mu \mathrm{g} / \mathrm{ml})$ concentration level. 


\section{Current Trends in Natural Sciences}

Vol. 10, Issue 20, pp. 53-60, 2021

https://doi.org/10.47068/ctns.2021.v10i20.008

Current Trends in Natural Sciences (on-line)

ISSN: 2284-953X

Current Trends in Natural Sciences (CD-Rom)

ISSN: 2284-9521

ISSN-L: 2284-9521

ISSN-L: 2284-9521

\section{CONCLUSIONS}

The reduction of silver nitrate and chloroauric acid to silver nanoparticles and gold, respectively, was confirmed by the FTIR spectroscopy technique. The lowest phytotoxicity was observed at the variants with $A$. scolopendrium extracts 1:10 dilution, where was observed a root and stem growth stimulation.

\section{ACKNOWLEDGEMENTS}

This work was carried out within the project "Obtaining new phytosynthesized biomaterials with antimicrobial potential, no. CIPCS-2020-08" funded by the University of Pitesti

The authors also acknowledge the support obtained through a grant of the Ministry of Research, Innovation and Digitization, CNCS/CCCDI - UEFISCDI, project number PN-III-P4-ID-PCE-2020-0620, within PNCDI III

\section{REFERENCES}

Alshehddi, L.A.A., Bokhari, N. (2020). Influence of gold and silver nanoparticles on the germination and growth of Mimusops laurifolia seeds in the South-Western regions in Saudi Arabia. Saudi Journal of Biological Sciences, 27(1), 574-580. doi:10.1016/j.sjbs.2019.11.013

Aqeel, U., Aftab, T., Khan, M.M.A., Naeem, M., Khan, M.N. (2021). A comprehensive review of impacts of diverse nanoparticles on growth, development and physiological adjustments in plants under changing environment. Chemosphere. https://doi.org/10.1016/j.chemosphere.2021.132672

Arora, S., Sharma, P., Kumar, S., Nayan, R., Khanna, P.K., Zaidi, M.G.H. (2012). Gold-nanoparticle induced enhancement in growth and seed yield of Brassica juncea. Plant Growth Regulators, 66, 303-310

Barabanov, P.V., Gerasimov, A.V., Blinov, A.V., Kravtsov, A.A., Kravtsov, V.A. (2018). Influence of nanosilver on the efficiency of Pisum sativum crops germination. Ecotoxicology and Environmental Safety, 147, 715719. doi:10.1016/j.ecoenv.2017.09.024

Dobrucka, R., Romaniuk-Drapala, A., Kaczmarek, M. (2021). Facile synthesis of Au/ZnO/Ag nanoparticles using Glechoma hederacea L. extract, and their activity against leukemia. Biomedical Microdevices, 23(1), 14, DOI 10.1007/s10544-021-00557-0

Eckel, R., Huo, H., Guan, H.-W., Hu, X., Che, X., and Huang, W.-D. (2001). Characteristic infrared spectroscopic patterns in the protein bands of human breast cancer tissue. Vibrational Spectroscopy, 27, 165-173

Ghosh, S., Rana, D., Sarkar, P., Roy, S., Kumar, A., Naskar, J., Kole, R.K. (2021). Ecological saferty with multifunctional applications of biogenic and bimetallic ( $\mathrm{Au}-\mathrm{Ag}$ ) alloy nanoparticles. Chemosphere, 132585, https://doi.org/10.1016/j.chemosphere.2021.132585

Hu, J., Xianyu, Y. (2021). When nano meets plants: A review on the interplay between nanoparticles and plants. Nano Today, 38, 101143. doi:10.1016/j.nantod.2021.101143

Huleihel, M., Salman, A., Erukhimovich, V., Ramesh, J., Hammody, Z., Mordechai, S. (2002). Novel optical method for study of viral carcinogenesis in vitro. Journal of Biochemical and Biophysical Methods, 50, 111-121

Hussain, M., Raja, N.I., Iqbal, M., Ejaz, M., Aslam, S., Rehman, A.-U., Javaid, U. (2018). Seed germination and biochemical profile of Citrus reticulata (Kinnow) exposed to green synthesised silver nanoparticles. IET Nanobiotechnology, 12(5), 688-693. doi:10.1049/iet-nbt.2017.0303

Hussain, M., Raja, N.I., Mashwani, Z.-U.-R., Iqbal, M., Sabir, S., Yasmeen, F. (2017). In vitro seed germination and biochemical profiling of Artemisia absinthium exposed to various metallic nanoparticles. 3 Biotech, 7(2). doi:10.1007/s13205-017-0741-6

Jogaiah, S., Paidi, M.K., Venugopal, K., Geetha, N., Mujtaba, M., Udikeri, S.S., Govarthanan, M. (2021). Phytotoxicological effects of engineered nanoparticles: An emerging nanotoxicology. Science of The Total Environment, 801, 149809. doi:10.1016/j.scitotenv.2021.149809

Jurkow, R., Pokluda, R., Sękara, A., Kalisz, A. (2020). Impact of foliar application of some metal nanoparticles on antioxidant system in oakleaf lettuce seedlings. BMC Plant Biology, 20(1). doi:10.1186/s12870-020-02490-5

Kiefer, J., Grabow, J., Kurland, H-D, Müller, F.A., (2015). Characterization of nanoparticles by solvent infrared spectroscopy. Anal. Chem., 87(24), 12313-12317, https://doi.org/10.1021/acs.analchem.5b03625 


\section{Current Trends in Natural Sciences}

Vol. 10, Issue 20, pp. 53-60, 2021

https://doi.org/10.47068/ctns.2021.v10i20.008

Current Trends in Natural Sciences (on-line)

ISSN: 2284-953X

Current Trends in Natural Sciences (CD-Rom)

ISSN: 2284-9521

ISSN-L: 2284-9521

ISSN-L: 2284-9521

Khan, M., Khan, M.S.A., Borah, K.K., Goswami, Y., Hakeem, K.R., Chakrabartty, I. (2021). The potential exposure and hazards of metal-based nanoparticles on plants and environment, with special emphasis on $\mathrm{ZnO} \mathrm{NPs}$, TiO2 NPs, and AgNPs: A review. Environmental Advances. 6, 100128, ISSN 26667657.https://doi.org/10.1016/j.envadv.2021.100128.

Kumar, N., Tripathi, P., Nara, S. (2018). Gold nanomaterials to plants. Nanomaterials in Plants, Algae, and Microorganisms, 195-220. doi:10.1016/b978-0-12-811487-2.00009-8

Labeeb, M., Badr, A., Haroun, S.A. Mattar M.Z., El-Kholy A.S., El-Mehasseb I.M., (2020). Ecofriendly synthesis of silver nanoparticles and their effects on early growth and cell division in roots of green pea (Pisum sativum L.). Gesunde Pflanzen, 72:113-127.https://doi.org/10.1007/s10343-019-00491-5

Lucassen, G.W., Van Veen, G.N., Jansen, J.A. (1998). Band analysis of hydrated human skin stratum corneum attenuated total reflectance Fourier transform infrared spectra in vivo. Journal of Biomedical Optics, 3, 267-280

Mehmood, A., Murtaza, G. (2017). Impact of biosynthesized silver nanoparticles on protein and carbohydrate contents in seeds of Pisum sativum L. Crop Breeding and Applied Biotechnology, 17(4), 334-340. doi:10.1590/198470332017v17n4a51.

Mordechai, S., Salman, A.O., Argov, S., Cohen, B., Erukhimovitch, V., Goldstein, J., Chaims, O., Hammody, Z. (2000). Fourier-transform infrared spectroscopy of human cancerous and normal intestine. Proceedings of the SPIE, 3918, 66-77.

Ndeh, N.T., Maensiri, S., Maensiri, D. (2017). The effect of green synthesized gold nanoparticles on rice germination and roots. Advances in Natural Sciences: Nanoscience and Nanotechnology, 8(3), 035008. doi:10.1088/20436254/aa724a .

Prażak, R., Święciło, A., Krzepiłko, A., Michałek, S., Arczewska, M. (2020). Impact of Ag nanoparticles on seed germination and seedling growth of green beans in normal and chill temperatures. Agriculture, $10(8), 312$. doi:10.3390/agriculture10080312.

Rahman, M.S., Chakraborty, A., Mazumdar, S., Nandi, N. C., Bhuiyan, M. N. I., Alauddin, S. M., Khan, I.A., Hossain, M. J. (2020). Effects of poly(vinylpyrrolidone) protected platinum nanoparticles on seed germination and growth performance of Pisum sativum. Nano-Structures \& Nano-Objects, 21, 100408. doi:10.1016/j.nanoso.2019.100408 .

Rani, M., Keshu, Shanker, U. (2022). Green nanomaterials: An overview. Green Functionalized Nanomaterials for Environmental Applications, Micro and Nano Technologies, 43-80, https://doi.org/10.1016/B978-0-12-8231371.00026-9.

Rani, P., Gaurav, S.S., Trivedi, L., Singh, A., Shukla, G. (2021). Assessment of nanotoxicity of silver nanoparticles on pea (Pisum sativum) grown under ex situ conditions. Journal of Stress Physiology \& Biochemistry, 17(2), 20-34 ISSN 1997-0838.

Sahu, S., Sharma, S., Ghosh, K. K. (2020). Novel formation of Au/Ag bimetallic nanoparticles by a mixture of monometallic nanoparticles and their application for rapid detection of lead in onion sample. New Journal of Chemistry. doi:10.1039/d0nj02994g.

Schulz, H., Baranska, M. (2007). Identification and qualification of valuable plant substances by IR and Raman spectroscopy. Vibrational Spectroscopy, 43, 13-25.

Shetty, G., Kedall, C., Shepherd, N., Stone, N., Barr, H. (2006). Raman spectroscopy: evaluation of biochemical changes in carcinogenesis of oesophagus. British Journal of Cancer, 94, 1460-1464.

Siddiqi, K.S., Husen, A. (2016). Engineered gold nanoparticles and plant adaptation potential. Nanoscale Research Letters, 11(1). doi:10.1186/s11671-016-1607-2 .

Szymanski, M., Dobrucka, R. (2020). Evaluation of phytotoxicity of bimetallic Ag/Au nanoparticles synthesized using Geum urbanum L. Journal of Inorganic and Organometallic Polymers and Materials. doi:10.1007/s10904-02001814-0 .

Taylor, A.F., Rylott, E.L., Anderson, C.W.N., Bruce, N.C. (2014). Investigating the toxicity, uptake, nanoparticle formation and genetic response of plants to gold. PLOS ONE, 9(4), e93793. doi:10.1371/journal.pone.0093793.

Tripathi, D.K., Singh, S., Singh, S., Srivastava, P.K., Singh, V. P., Singh, S., Prasad, S.M., Singh, P.K., Dubey, N.K., Pandey, A.C., Chauhan, D. K. (2017). Nitric oxide alleviates silver nanoparticles (AgNps) - induced phytotoxicity in Pisum sativum seedlings. Plant Physiology and Biochemistry,110, $167-177$. doi:10.1016/j.plaphy.2016.06.015

Wang, H.P., Wang, H.-C., Huang, Y.-J. (1997). Microscopic FTIR studies of lung cancer cells in pleural fluid. Science of the Total Environment, 204, 283-287 


\section{Current Trends in Natural Sciences}

Vol. 10, Issue 20, pp. 53-60, 2021

https://doi.org/10.47068/ctns.2021.v10i20.008

Current Trends in Natural Sciences (on-line)

ISSN: 2284-953X

Current Trends in Natural Sciences (CD-Rom)

ISSN: 2284-9521

ISSN-L: 2284-9521

ISSN-L: 2284-9521

Yang, Y., Sule-Suso, J., Sockalingum, G.D., Kegelaer, G., Manfait, M., El Haj, A.J. (2005). Study of tumor cell invasion by Fourier transform infrared microspectroscopy. Biopolymers, 78, 311-317.

Zhu, Z.-J., Wang, H., Yan, B., Zheng, H., Jiang, Y., Miranda, O. R., Rotello, V.M., Xing, b. Vachet, R.W. (2012). Effect of Surface Charge on the Uptake and Distribution of Gold Nanoparticles in Four Plant Species. Environmental Science \& Technology, 46(22), 12391-12398. doi:10.1021/es301977. 